\title{
Wainwright's West Yorkshire: affect and landscape in the television drama of Sally Wainwright
}

Article

Accepted Version

Woods, F. (2019) Wainwright's West Yorkshire: affect and landscape in the television drama of Sally Wainwright. Journal of British Cinema and Television, 16 (3). pp. 346-366. ISSN 1755-1714 doi: https://doi.org/10.3366/jbctv.2019.0481 Available at https://centaur.reading.ac.uk/81364/

It is advisable to refer to the publisher's version if you intend to cite from the work. See Guidance on citing.

To link to this article DOI: http://dx.doi.org/10.3366/jbctv.2019.0481

Publisher: Edinburgh University Press

All outputs in CentAUR are protected by Intellectual Property Rights law, including copyright law. Copyright and IPR is retained by the creators or other copyright holders. Terms and conditions for use of this material are defined in the End User Agreement.

www.reading.ac.uk/centaur 
Central Archive at the University of Reading

Reading's research outputs online 


\section{Wainwright's West Yorkshire: Affect and Landscape in the Television Drama of Sally Wainwright}

Faye Woods

Sally Wainwright's television dramas display an investment in exploring the emotional landscapes of women's personal and working lives, built on plain talk, sharp wit and complex female relationships. We might consider the quintessential Sally Wainwright scene as two women sitting talking. In looking at the work of a writer so invested in intimate interactions, looking outwards to space and place could seem counterintuitive. But as the growing body of academic studies of the writer has repeatedly noted, Wainwright's work is rich in both women's voices and a sense of place (Gorton 2016; Piper 2016, 2017; McElroy 2017). Her television dramas return time and again to the geographic spaces of West Yorkshire, interweaving an investment in the emotional dynamics of Northern women's lives with an investment in Northern landscapes. Here I echo Rachel Moseley's work on the gendered imagery of Cornish representations across film and TV (2013) to think about the place-image (Shields 1992) of West Yorkshire that Wainwright's television dramas trace and layer. This is charted through a triangulation of spaces that Wainwright returns to and re-treads across her work: the Calder Valley, Halifax, Harrogate, Haworth and the land that surrounds them; what I term here Wainwright's West Yorkshire. By identifying how these landscapes are mobilised affectively to support emotion-centred narratives, I analyse an investment in sense and sensibility across her women and the West Yorkshire landscapes they inhabit.

By focusing on space and place and the women embedded within it, I develop Kristyn Gorton's assertion that Wainwright 'weaves place with emotion' to create a distinctively Northern "structure of feeling"' (2016: 80). I frame Wainwright's structure of feeling as a combination of 'sense' and 'sensibility' (to steal from Jane Austen), weaving stories centred on plain talking, sensible women and the complex emotional lives that they struggle to contain. This extends to the affective power of the West Yorkshire landscape: enduring and everyday; its hills, valleys and moorland are travelled through and laboured upon, but have the potential for natural spectacle and affective power.

Looking across Wainwright's lengthy body of work, I pick out three dramas that 
draw out commonalities in their affective engagement with space. Last Tango in Halifax (BBC1, 2012-2016) and Happy Valley (BBC1, 2014-) are fruits of Wainwright's long term working relationship with independent production company Red Productions, the focus of this special issue. (ITV's Scott \& Bailey (2011-2016) is an outlier during this period due to its Manchester setting). To Walk Invisible (BBC1, 2016) is a co-production with BBC Wales and independent production company Looking Point, as is Wainwright's Gentleman Jack (BBC1, 2018), currently in-production. These latter programmes are period dramas, a specialism of Looking Point, in contrast to RED's contemporary focus. The Brontë biopic goes beyond this issue's focus on RED, but it offers a valuable contribution to the discussion of Wainwright's West Yorkshire. The programme's focus on the Brontë sisters and their connection with the moor clearly articulates how Wainwright's affective engagement with the landscape can be positioned within a sensual place-image built from female voices, of which the sisters are a foundational part.

Across these dramas Wainwright has worked with a roster of different directors and creative teams. I'm not fond of the 'auteur' discourses which tend to surround television writers and 'prestige' drama, as televisual storytelling is a team game, and no one creative should be privileged as the author of a programme's gaze. But I do place the storytelling and affective investment of these programme's under Wainwright's authorship, as she has been an executive producer on several of her works for RED and now increasingly directs these dramas. Recent academic work on Wainwright has sought to position her as one of the most significant creatives in contemporary television, tracing commonalities across Wainwright's dramas: an interest in working women and the social anxieties that surround them; the rendering of a distinctly classbased experience; the depiction of emotional labour; and the complexity of friendship and familial bonds (Gorton 2016; Piper 2016, 2017; McElroy 2017).

Gorton usefully intertwines melodrama with social realism to position Wainwright's work as a corrective to the latter's historic investment in the emotional journeys of men (2016: 78). I follow Gorton in claiming Wainwright for melodrama, particularly familial melodrama, the framework within which her crime dramas, romances and literary biopics sit. Across my chosen programmes we see moments of moral quandary and emotional fracture that draw audiences close and make hearts 
race. Framing these programmes as melodrama allows me to consider the expressive potential of landscape, following Jennifer Peterson's assertion that landscape can add 'emotional tone' to melodrama, 'wordlessly signifying a host of other meanings not voiced in dialogue' (2010: 136). My chosen dramas blend emotional spectacle with fragments of landscape spectacle; both can teeter at the edge of the sublime, able to take your breath away.

I offer here a distinctly gendered reading of television's recent 'spatial shift' (Roberts: 2016) by framing Wainwright's affect-driven storytelling as part of a layering of female gazes and voices that has rendered the West Yorkshire region across different creative mediums. In particular the novels and poems of the Brontë sisters and the legend that surrounds them, fragments of Sylvia Plath's poetry, and the landscape photography of Fay Goodwin. I shift away from the conventional tendency to consider Northern landscapes through a framework of social realism by drawing out a placeimage of West Yorkshire created by affect and texture, melodrama and traces of the gothic. These programmes draw from different genres - family drama, crime drama and period biopic - and depict themes and variation in their affective engagement with West Yorkshire landscapes.

\section{Televisual landscapes}

This article contributes to the growing engagement with geographic visuality within television studies, which has emerged in response to the booming 'geography genre' of factual programming (Wheatley 2011, 2016), the popularity of imported 'Nordic Noir' crime drama and TV drama's increased investment in location shooting. Helen Piper suggests television's 'once interchangeable backdrops' are now often positioned as spectacular objects of the gaze (2016: 176). This is illustrated by two Wainwright dramas set in the Calder Valley, with the crime drama Happy Valley showcasing a marked increase in engagement with the valley's landscape and its storytelling potential when compared to her earlier family melodrama Sparkhouse (BBC1, 2002).

The investigatory gaze and invitation to look offered by crime dramas such as Happy Valley (Donaldson 2016: 11) have seen the genre - particularly Nordic Noir dominate discussions of television drama's use of landscape (Roberts, 2016; Piper 2016). The programmes I discuss here share Nordic Noir's use of landscape imagery to 
signal mood and emotion, underscore emotional states, and create a distinct visual style (Marit Waade 2017: 388). However, I extend discussion of television's landscapes beyond crime drama to consider a particular regional place-image entwined with melodrama and the gothic.

Helen Piper links the recent rise in location shooting to an assertion of national identity in a globalised television market, suggesting the spatial dynamics of Happy Valley presents Catherine's perspective as a native view of the Yorkshire landscape rather than a tourist gaze (178). Piper's 'native' view is distinct from that attributed to the protagonists of 1960s social realist cinema by Andrew Higson. He argued influentially that the spatial systems of these films align with external perspectives (including those of their middle- and upper-class directors), naturalising their male protagonists' desire to escape from their Northern towns (1984). Instead, Wainwright's female protagonists are intertwined indelibly with the West Yorkshire spaces they inhabit. This is rendered through an embrace of the affective potential of landscape, contributing to the emotional work that is these programmes' central pleasure.

Television's serialised structure and long-running narratives offer a specifically televisual structuring of our experience of space, mapping our experience of familiar spaces through repetitions and returns (Donaldson 2016: 5-6). Wainwright's repeated returns to the region build a place-image across episodes, seasons, and programmes. Each programme's storytelling layers different emotional textures onto the same geographic topography. These topographic returns are emphasised by compositional systems (particularly establishing shots, as I will demonstrate) and montage. Televisual montage works to fold landscape into the narrative of these dramas, as 'montage is to television spectacle what the long take and wide angle shot are to filmic spectacle' (Wheatley 2016: 133). Across these dramas we contemplate a space briefly, then are moved on across or into it, integrating landscape more strongly into Wainwright's affect-driven storytelling than the lingering contemplation Wheatley finds in the factualdriven 'landscape mode' (125).

\section{Building a place-image}

Wainwright's work charts a personal geography (Thornham 2016: 218) - of the region and of the women's emotional and work life - that contributes to the place-image of West Yorkshire shaped by a lineage of earlier women's encounters with the region. This 
imagery feeds into the 'Northern Gothic' that Het Phillips (2017: 155) suggests binds the dramatic landscapes of the region with the 1960s Moors Murders and literary traditions that include Emily Brontë's Wuthering Heights (1847). Wainwright's West Yorkshire shows traces of the Northern Gothic, rendered here in a female-centred affective mode. The emotional textures of both Wainwright's work and the place-image of West Yorkshire it informs draw on the ability of landscapes to layer meaning onto storytelling. These programmes imbue the same landscapes with different emotional textures, with Wainwright's repeated returns to West Yorkshire building a place-image through theme and variation.

In this respect I follow Rachel Moseley's work on gendered imagery and Cornish representations (2013), which explores the county's liminal place-image through repeated encounters with the image of the woman on the cliff edge across painting, film and television. Wainwright's West Yorkshire interweaves with the cultural legacies of the region and 'the moors', particularly its female voices and affective undercurrent. Like Moseley, I don't trace a direct connection across these texts instead viewing them as 'participants in the construction and reproduction of a particular place-image ... one which is mobilized in quite particular, affective ways' (2013: 647). These female voices and visions have presented these landscapes through a range of inflections, reading them as realist, Romantic and gothic.

My chosen programmes range across the Calder Valley, described by William Atkins in his travelogue The Moor as 'a ditch made dim by its narrowness' (2015: 147). This is evoked by Sylvia Plath in her 1961 poem 'Wuthering Heights' 'Now, in valleys narrow / And black as purses, the house lights / Gleam like small change' (2002: 168). Last Tango in Halifax, Happy Valley and To Walk Invisible move through Heptonstall, Sowerby Bridge and Hedben Bridge across to Halifax, moving north westwards to the Brontë's Haworth and further north east to Harrogate. Tracing across these spaces are echoes of female voices and views which frame the region, from the Brontë sisters and their film and televisual adaptations, to the poetry of Plath, and the landscape photography of Fay Goodwin.

Wainwright's West Yorkshire is layered with 'Brontë Country', a term that illustrates the sisters' status in English literature and highlights how their novels and 
biographic legends are layered onto the region's landscape (Lawrence 2016: 180). We can consider the Brontë myth as a central marker of this West Yorkshire's place-image. The Haworth parsonage's liminal placement at the edge of the moorland intertwines with the sisters' fiction and poetry to draw out an affective engagement with the land and female interiority. Sylvia Plath responds to this and also her own encounters with the moorland landscapes that inspired Emily Brontë in her poem that shares the novel's name. This evokes her affective encounter with this sublime yet brutal landscape:

There is no life higher than the grass tops

Or the hearts of sheep, and the wind

Pours by like destiny, bending

Everything in one direction

I can feel it trying

To funnel my heat away (Plath 2002, 167)

Plath's gravestone is at Heptonstall (and is seen in Happy Valley), where she travelled to join her husband, poet Ted Hughes. Hughes worked with Faye Goodwin on their book Remains of Elmet (1979), in which Goodwin's photography of the Calder Valley sits alongside the poems they inspired (which themselves are laced with evocations of the Brontës). The place-image of the region is woven from these collections of voices and views, to which Wainwright's work contributes, offering a multi-layered tactile, affective rendering of West Yorkshire.

Sue Thornham evokes this layering in her discussion of Goodwin's photography, which addresses us

through texture, touch and a form of intimate witnessing, rather than through the formal framings of landscape... It is as if she is seeking to reach into, and rip apart, the smooth surface of the landscapes that are her subject matter, to highlight the visceral detail and non-human life, and death, that they conceal. (2016: 221)

Goodwin's landscape photography constructs the region as a space of stark, sublime beauty, largely empty of inhabitants. As Margaret Drabble notes 'There are no people in most of her landscapes ... only the traces of people, the remains of people' (Drabble 
2011). The West Yorkshire landscapes presented across Wainwright's work at times retain this sublime beauty, and particularly evoke the textures of light across its hills and expanses. Yet Wainwright's West Yorkshire is an inhabited and embodied land, with towns arrayed across valleys. Desolate moorland and windswept hills are cut through by roads and pylons, or parcelled into squares of working farmland. These function as the background to heritage towns whose supermarkets and tea shops sit alongside the stone-hewn ghosts of their industrial pasts. Yet her affect-driven storytelling and investment in the complexity of her female protagonists evokes Thornham's description, here 'seeking to reach into, and rip apart, the smooth surface', of families and society.

Thornham traces connections between Goodwin, Emily Brontë, and Andrea Arnold's poetic, brutal and intensely haptic interpretation of Wuthering Heights (2011). Brontë's novel is perhaps the foundation stone of the place-image of the region, yet as both Thornham (219) and Michael Lawrence (181) note, the Yorkshire moors elude direct description in her novel. Rather it is the subsequent film and televisual adaptations that have built the affective imagery of the region. Thornham presents this imagery as a drawing out of the 'personal landscapes' of the novel, with Arnold's film transforming its sensations of a 'space without boundaries' into a tactile relationship with the landscapes of the moors (2016: 219-22). These layering of representations render the place-image of West Yorkshire as wrought through brutal beauty, built through female voice and views, to which Wainwright is the latest contributor.

In the three dramas I select here, the natural spaces of West Yorkshire are rarely autonomous landscapes and serve multiple affective pleasures. Last Tango in Halifax constructs this as both leisure and labouring land; the special dynamic of Happy Valley uses the landscape to build the town as the oppressive, bounded space of melodrama; and To Walk Invisible reads the moorland as both everyday and sublime, central to the Brontë sisters' spiritual and creative sustenance. The landscapes of Wainwright's West Yorkshire serve as geographical markers facilitating narrative, and also work affectively to draw out elements of melodrama and the gothic that are woven through these familial and crime dramas. All three programmes present an interplay between these majestic and everyday landscapes and the complex lives of the women embedded in them, read through 'sense' and 'sensibility'.

\section{Last Tango in Halifax}


Last Tango in Halifax depicts widowed pensioners Alan and Celia, reunited childhood sweethearts who embark on a late-in-life whirlwind romance. A blend of romantic comedy and family melodrama, the programme charts the impact of their coupling on their middle-aged daughters and their own families. Alan lives with his widowed daughter Gillian who runs a farm near Halifax, and Celia lives with her daughter Caroline, a private school headmistress in Harrogate near Leeds. With Alan and Celia living sixty miles apart, the regional landscapes are made familiar through repeated car journeys between family homes, the topographic repetitions of serial television (Donaldson 2016: 6). These homes signify the families' class difference, contrasting the rough-hewn isolation of Gillian's farmhouse, with Caroline's grand yellow-stone suburban Victorian villa. The programme renders the West Yorkshire landscape that separates them as both everyday and spectacular, drawing on these spaces to support the narrative's investment in Alan and Celia's romance and Gillian's emotional complexity.

The landscape between and around Halifax and Harrogate is presented as a leisure space charted by our financially-secure elderly lovers, across moorlands and valleys, and through picturesque market towns. Episodes are punctuated with mini road trips in which West Yorkshire is both a laborious and occasionally threatening expanse to be traversed, and a sight to be dwelt upon pleasurably. These journeys offer repeatedly offer us moments in which to contemplate the landscape's beauty or majesty in an sweeping wide shots or 'spectacular montage' (Wheatley 2016: 133). These expanses of bucolic or windswept landscapes are then brought down to earth and exchanged for the shot-reverse-shot intimacy of car-bound conversations.

The spaces of the region are aligned with Alan and Celia's strong local roots (Celia left Halifax for Leeds as a teenager) and its sublime landscapes accompany moments of reflection on their romantic reunion. In these scenes the timelessness of this land, these hills of ancient stone, are intertwined with their - always resolutely practical - contemplations of romantic destiny. In episode three of season one, a sequence opens with the couple's car framed at the base of a large wide shot of a sublime moorland landscape at dusk, heavy grey clouds almost touching the stone and snow-strewn hills, a sharply angled shard of water occupies centre-screen with their car small in the foreground [figure 1]. We move from the vast exterior - Buckstones Ridge, a 
location Celia names as resonant in their shared local history - into the intimate, romantic space of the car as they hold hands, and, in a series of two shots and shotreverse-shots, ponder their relationship. Here the eternal nature of this landscape signals their romantic destiny, their aborted teenage love has endured like the landscape.

Similarly, in season 2 episode 1, the pair are perched on a rocky outlook after Alan has been released from hospital. They take in the view as they discuss his perspective on life following a heart attack and reminisce about their childhood adventures there. This positioning layers the scene with memories of other romantic couples aligned with the Yorkshire landscape. Adaptations of Emily Brontë's Wuthering Heights signal Cathy and Heathcliffe's destructive eternal love and inherent wildness through their affinity with the forbidding, windswept Yorkshire moorlands, which are used to 'emphasise "transcendental" or "eternal" aspects of the human relationship at the centre of the story' (Lawrence 2016: 181). Here, the elderly Alan and Celia's intimate romance is given grandeur by its positioning within the spectacular spring landscape. However, in contrast to Cathy and Heathcliffe's sublime moorland, this is rendered as picturesque with drifting blossom, gentle wind and sunlight. The West Yorkshire landscape is here aligned with the personal histories of Alan and Celia and is their forthright personalities, yet its place-image aligns with their impulsive embrace of romance - they plan to wed in secret - with the region's Romantic lineage, sense and sensibility are paired. The strength of their romantic connection, entwined with their Yorkshire roots, is carried through the stones they sit upon, worn smooth by the winds, with aged graffiti carved into its surface. But the scene's focus is on the couple and their interaction over the wider space they are placed within, as the shot systems position them within moorland beauty, but we are denied the view the contemplate. Instead we focus on their intimate, nostalgic and contemplative conversation.

For Alan and Celia, the West Yorkshire landscapes are spaces of leisure, with the land signalling the naturalness of their connection, whereas for Alan's daughter Gillian this is labouring land. Celia's daughter Caroline is connected strongly to the uppermiddle-class comfort of her spacious Harrogate home and her high-status headmistress job. Both are the focus of the disruptions and frustrations Caroline endures through the destructive actions of her estranged husband, and her romance with a female colleague. 
In contrast Gillian holds a particular connection with the outdoors and the West Yorkshire landscape, with her farm presented as a passion, but also a financial struggle since the death of her husband, now maintained by her father's financial help and her supermarket job. In season one, she is strongly connected with the land, frequently pictured labouring on the farm and its machinery. Frequently wet and windswept, Gillian has a sensible and practical relationship with this land. Het Phillips notes that the Northern body tends to be positioned 'as working-class and tough: as the enduring body, the labouring body' (2017: 155). Like the land of her farm, Gillian endures. Yet the farm also weighs down on her; as with Catherine in Happy Valley, she is a haunted woman repressing grief and guilt. The barn features as a looming reminder of her role in her hated husband's suicide. The shot-reverse-shots of her lingering, fearful gaze upon it depict this violent act as embedded in this land's memory. The barn as a space of gothic memory is drawn out more strongly in season two as she verbalises fully her guilt and confesses that his death was manslaughter, a response to her husband's abuse. This dark secret draws out the trace of Northern gothic woven into Last Tango through its hints of the haunted Northern landscape (155). But, unlike Happy Valley this is not the dominant reading of the farm, just a flicker across its land and a weight on Gillian's soul, part of Wainwright's blend of sense and sensibility.

Despite her sensible plain-speaking nature and practical life, there is something of the gothic heroine in Gillian, with her violent marriage and dark secret, her selfdestructive nature and her rough, close-to-the ground sexuality. She is frequently positioned as an object of male desire and enjoys an active sex life, although one driven by self-destructive tendencies. She echoes the teenage Carol in Wainwright's 2002 serial Sparkhouse, a family melodrama built around a cross-class teen romance. Carol is depicted as the teenage female Heathcliff of this pseudo-adaptation of Wuthering Heights, and, like Gillian, she is linked to the land, working on her family's ramshackle farm. Both women are wilful and earthily sexual; Carol is wild and passionate whereas Gillian has become practical in her middle-age. In her combination of practicality, guilt and sexuality, Gillian embodies sense and sensibility, much like her farmland, which is shown as tough and labouring yet also sensual and majestic.

This duality is illustrated in the two recurring framings of the farm within the landscape, its isolation enfolding Gillian and Alan's family into the land Gillian works. 
Shots that look up the hill across farmland to the farmhouse are cast in a gloomy palette, with wind turbines on the skyline and machinery and scrubby farmland in fore- and mid-ground as Gillian's ancient land rover rattles up the lane. Here West Yorkshire is offered as tough labouring land, with a muscled beauty. However, more frequently used is the reverse angle position with the driveway in the foreground, looking down the valley from Rippendon to Halifax below, wreathed in fog, rain clouds, shimmering dawn or clear sunlight. As a narrative built around a middle-distance romance, arrivals and departures focus much narrative action on this driveway, set against the spectacular view that surrounds it. The first visit of the middle-class Harrogate family in episode two is framed against this vista, and they exclaim at its beauty in the low winter golden sunlight. Yet both Gillian and Alan are at pains to highlight the bitter brutality of this landscape when winter comes, and speculate over the middle-class Celia's ability to endure it. This also serves to emphasise Gillian's strength in her endurance of and love for the space.

As a blend of family drama and romantic comedy, Last Tango in Halifax deploys its landscapes with a light touch. Land is rendered as both labouring and leisure-space, practical and everyday, yet also offering moments of sublime romanticism that evoke West-Yorkshire's place-image through which Alan and Celia's romance is read. Although the couple indulge in the heritage tourism of the region, this rooting of their romance in the region offers 'a native rather than a tourist view of a very British and specifically Yorkshire landscape' (Piper 2016: 178 emphasis in original). Gillian's identity is embedded in her land, with her own, and the landscape's, duality embodying the sense and sensibility of Wainwright's place-image. She endures, as does the land with which she is linked.

\section{Happy Valley}

The most-discussed programme in Wainwright's oeuvre, Happy Valley has been the subject of particular academic interest in its affective and moral investments (Gorton 2016; Piper 2016, 2017; McElroy 2017). These are intertwined in the authors' exploration of women's work and its Northern setting. Centred on Sowerby Bridge, and ranging across the Calder Valley, Happy Valley employs the trope of the small town with the dark underside. A simple reading of its spatial dynamics could set out the drugridden town as the blighted darkness within the surrounding rural picturesque, but the 
programme draws out the affective potential of this landscape to support the narrative's emotionally-wrenching events.

The programme centres on Catherine Cawood, another of Wainwright's Yorkshire women of sense and sensibility. A plain-talking former detective who returned to uniform after her daughter's rape and suicide, Catherine is now a highly experienced police sergeant. Season one interweaves her working life and family pain, as she struggles to barely suppress the fear, rage and guilt catalysed by the return to town of her daughter's rapist Tommy Lee Royce, the father of her grandson Ryan. As Gorton explores, Wainwright centres the drama on Catherine's emotionally fraught experience, 'almost physically working through the pain and loss she has suffered and finding a way out of her own emotional entrapment' (2016: 80). Tommy is involved subsequently in the kidnapping of a local businessman's daughter and the murder of a young policewoman who was Catherine's protégée. Her emotional turmoil and the impact of Tommy's violence is layered onto the town and surrounding valley, through compositional choices that position the landscape to subtly build an oppressive affect.

Piper reads Happy Valley as an unnamed Yorkshire 'every town' (178). However, the programme clearly marks out its geographical position, with characters frequently naming locations that position us in the Calder Valley region. Catherine radios her police identification address as Sowerby Bridge; PC Kirsten McAskill dies on the road outside Rippendon; Ann is kidnapped driving to Huddersfield; Tommy Lee Royce's mother talks of the junkies down in Hebden Bridge; Ryan tells Tommy about visiting his mother's grave up at Heptonstall (where he encounters the grave of Sylvia Plath). Although visually these spaces can blend together, these passing locational fragments work to position the narrative space geographically and frame the storytelling within regional boundaries. Like the Oxford of Inspector Morse (ITV, 1987-2000), these specific localities build 'a series of accumulated images contributing to a larger, layered composition' (Donaldson 2016: 23). These traces position Happy Valley within the place-image of Wainwright's West Yorkshire, weaving the programme into the layers of female voice that have explored the region.

The emotional journeys of Happy Valley's protagonists are intertwined with the 
landscape's spatial dynamics. Shots of the town are framed frequently to show the valley's hills present in backgrounds and between buildings, thereby enforcing geographic boundaries and spatial blockages. The valley's hills rise up behind houses at the street end, crowding out the skyline as Catherine slams Tommy against a wall and threatens him for following Ryan in episode 4. Episode 5 open with Catherine lying in the middle of the street, battered, bloodied and gasping for breath after rescuing Ann from Tommy, her body framed by the terraced houses whose perspective draws the viewer's attention to the hills beyond. These spatial dynamics present the valley as the bounded, oppressive space of melodrama, not easily escaped. This is very similar to Catherine's emotional state and the plot dynamics, which close in on the motley band of kidnappers as they hide from the police. The roads out of the town and into the surrounding hills are transitional, liminal spaces. Dark violence against women in the kidnapping of Ann and the murder of PC Kirsten McAskill plays out amidst expanses of windswept beauty. The murder scene opens out into sublime low horizons and cloudheavy dusk skies as Catherine reaches the location, which makes manifest the weight of yet more grief settling upon her.

Establishing shots are more frequent than is narratively necessary, with compositions positioning the town across and within the valley and its bordering hills. However, landscape shots from outside the town's borders appear infrequently; instead a system of extreme long shots offer distinctive spatial compositions that survey the town from on high, yet still remain within its boundaries. Rather than the spectacular and photogenic cityscape that Andrew Higson defines in 1960s social realist cinema as 'That Long Shot of Our Town from That Hill - a sort of in-between stage, where we are outside and above the city, but where the city itself is prominent within the frame' (1984: 13) this is That Long Shot from That Hill in Our Town. Where Higson's definition seeks to separate and signify its aspirational male working-class protagonist's desire to escape, Happy Valley's framing embeds Catherine, Tommy and the spaces they inhabit within the valley. The town's bordering hills are ever present, a contained, bounded, space.

The valley as a bounded space is compounded by other composition choices. Instead of using ground level long shots to establish narrative locations - the police station, the tower blocks, the allotment - these spaces are instead picked out in the 
foreground of wider shots that position them against the town and the hills in the background. Similar framing techniques occur at points in season one, when Catherine is seeking out Tommy, or he is concealing himself in the town. Rather than using streetlevel medium or panning shots, the investigating gaze of the crime drama seeks them out within the town. High-angled long shots centre them as tiny figures within wide shots that compress roads and houses against the valley's hills [Figure 2]. Here Wainwright uses the West Yorkshire place-image to enforce a sense of entrapment.

This oppressive landscape also persecutes Kevin Weatherill, one of Wainwright's string of weak yet arrogant men, and he serves as melodrama's crumbling, impaired, masculinity (Nowell-Smith 1977: 155). His pride catalyses the plot to kidnap and ransom Ann, the daughter of his boss, who Kevin believes cheated him out of the wealth he deserves. Like all the programme's aspiring middle-class families, including Catherine's ex-husband and his new partner, and her estranged son's family, Kevin's home backs onto the valley's steep brown and green hills. As he eats dinner with his wife and complains of his petty grievances, his kitchen conservatory looks out onto the rural vista he has achieved, lush green hills balanced against the steely blue sky. As the events of the narrative progress, and the kidnapping spirals into violence at the hands of Tommy, those hills come to signify Kevin's entrapment. As he makes desperate plans and phone calls in episode 2, he is framed against darkened windows where the valley's hills now blot out the sky.

Like Gillian in Last Tango in Halifax, Catherine endures, and this endurance is embedded within and signified by this regional space of sense and sensibility. In episode 5 , Caroline is finally placed up in the spatial freedom of the hills. Yet she is deeply depressed, sitting on a stone wall with her back to the valley, isolating herself from her family, denying herself and the viewer the potential emotional release of the view, which is hidden in fog. This freedom is signaled affectively and spatially in the closing sequence of season one, where Catherine's release from her emotional turmoil comes when she climbs a hill outside the town with her family. Following a memory montage that offers 'affective representation of her working through of the trauma' of narrative events (Piper 2016: 178), Catherine finally turns to tilt her face to the sun, positioned against the valley's hills in a 'Long Shot of Our Town From That Hill' (Higson 1984: 13): a prospect view. Her emotional release is signalled through spatial dynamics, yet this is not a sign of her 
desire for escape but, as Gorton argues, links her to place and a feeling of hope (2016: 82). Season one's conclusion illustrates how Happy Valley's raw, bitterly witty structure of feeling is deeply entwined with its sense of place, drawing on the melodrama and gothic tones embedded this place-image of West Yorkshire.

\section{To Walk Invisible}

I conclude with Sally Wainwright's interpretation of the lives of the Brontë sisters, whose romantic and gothic visions are one of the base layers of the place-image of West Yorkshire. 'Brontë country' and its 'romance of the marginal rural otherness' (Helsinger 2014: 177) is used to promote the area surrounding Haworth and across the South Pennine hills for tourism, and the sisters' biographical legend, its myths and the imagery of their literature are layered onto the region (Lawrence 2016: 190). To Walk Invisible presents the Brontës' relationship with the moorland as one of comfort and sustenance. These West Yorkshire landscapes evoke the sisters' practicality and endurance, blended with the sensuality their writing evidences. Wainwright presents both the moor and the emotional toil of their brother Branwell's alcoholism as the affective enablers of the sisters' gothic imaginations and eventual literary success.

Wainwright's childhood home of Sowerby Bridge is only a short distance from the Brontë's Haworth. She has written of how indelible the sisters' legend and literature were throughout her childhood (Wainwright 2016). Identifying her teenage investment in Wuthering Heights, she suggests its talk of the 'coarseness of real life', influenced her own writing voice. As this is the region that Wainwright returns to across her work, it is unsurprising that she would eventually tackle the story of Brontë sisters. Written and directed by Wainwright, To Walk Invisible made visible the spatial and emotional resonances of the Brontës that were always already part of Wainwright's work. In counterpoint, it could also be framed as Wainwright reads the family's story through her own investment in plain-speaking women and their vibrant interiorities; the affective and financial impact of male weakness, vanity and pride in their brother Bramwell's alcoholism; and the landscapes of West Yorkshire. To Walk Invisible presents the West Yorkshire lives and landscapes of Charlotte, Emily and Anne as pre-echoes of the sense and sensibility I've shown in both Gillian and Catherine. In particular we can built connections between these women and the drama's depiction of Emily as practical and 
brusque, embedded in the domestic, yet physically and emotionally intertwined with the moorland that borders the Brontë's Haworth vicarage. This positions her as a clear predecessor to Wainwright's other West Yorkshire heroines.

To Walk Invisible evokes the well-worn literary biopic trope of constrained female creatives with rich interior lives who must fight against cultural conceptions of female passivity (Jacobus 1981). Yet its presentation of the Brontës' childhood creativity and working lives is clearly aligned with Wainwright's investment in women's work, and with recent biographical attempts 'to redefine the Brontës, not as stranded, isolated geniuses of the moors but in such a manner as to present them as nineteenth-century intellectuals engaged with writing since young adulthood' (Maier 2016: 589). Where Happy Valley used landscape to enclose its characters, To Walk Invisible opens out the moorland in expansive wide and aerial shots that border on the sublime, positioning the sisters traipsing across and nestled within sweeping blankets of yellowed heather, clambering over craggy outcrops and contemplative in prospective views across steep gorges.

The drama's depiction of the sisters' relationship with the moorland aligns with recent film and televisual tendencies to present active heritage heroines, skirts billowing as they stride through or gaze across rough-hewn, sublime landscapes. These include Joe Wright's reworking of Pride and Prejudice (2005) that placed Elizabeth Bennett on the rocky outcrop of Stannage Edge in Derbyshire in sublime prospect views, and the active adventuring heroines of The Devil's Whore (Channel 4,2008) and Outlander (Starz, 2014-). Charlotte Brontë's Jane Eyre (1847) aligns her protagonist's interiority with the natural world, yet sees her suffer at the mercies of the unforgiving Derbyshire moorland when she abandons Thornfield Hall. Cary Fukunaga's 2011 adaptation captured this arduous journey, using wide shots that maroon Jane's billowing, stumbling, figure in vast sublime landscapes. In contrast, To Walk Invisible signals the Brontë sisters' fortitude through their comfort within and spiritual ownership of the spectacular moorland from which they draw sustenance.

Here the West Yorkshire moorland is presented as both every day and sublime, as sense and sensibility. It is a space particularly embraced by Ann and Emily, where its expanse offers escape from the emotional oppression of their brother Branwell's alcoholism, self-destructive behaviour, and manipulation of their father. The sisters sit 
enfolded in their skirts and the heather, or Ann is shown burrowed into Emily's lap. Much like Gillian in Last Tango in Halifax, Emily's comfort in the sisters' confident regular walks signals her earthy practicality and fortitude, the moorland an extension of her comfort in the parsonage's isolation. Yet Wainwright also employs the Romantic trope of landscape signifying wild interiority, with sweeping wide shots suggesting the literary imagination behind Emily's abrupt, practical persona. Here the drama offsets Emily's connection with the kitchen and domestic labour through a sensual evocation of the wild, sublime drama that Stella Hockenhull finds in recent adaptations of the Brontë novels. This she suggests blends Higson's 'dirty realist' (2010: 214-15) landscapes with imagery more in tune with Romantic literary traditions (Hockenhull 2016: 159). To Walk Invisible centres this interpretation through an intensely affective sequence that uses landscape to evoke the emotion and imagery of Emily's interiority. I chart this in detail as for me this signifies a culmination of Wainwright's affective engagement with this female-voiced place-image of West Yorkshire, in which Emily Brontë's poetry forms a foundational layer.

As Emily strides through the gate that borders the parsonage and clambers onto the yellow-heathered moor with her dog, her actions are crosscut with Charlotte reading for the first time the poems her sister has kept hidden. In a dark medium shot of Emily's bedroom, Charlotte sits centre-frame on the bed, silhouetted against the window as she reads in astonishment, quickly flicking through Emily's notebook. Fragments of these poems' stark beauty are read in voiceover by Emily, flowing over cross-cuts between her wordless, determined hiking and Charlotte's domestic enclosure. The swift, blunt, urgency of Emily's delivery of her words align with and seem to propel the fast pursuit of the aerial shot that places her figure within huge wide shots of the moorland and stream. The affective work of this sequence blends the passion of the poems, the shock of Charlotte's encounter with her sister's concealed interiority and the physicality of Emily's striding body, with words and actions combining to conjure goose-bumps and a racing heart. Emily determinedly hikes across the craggy land, easily navigating it in voluminous skirts whose neutral tones mimic the yellow and browns of the hills. Her expression looks inward rather than marvelling outwards, conveying the sense of her comfort within this landscape, and her stoic engagement with the physicality of the hike. The camera breaks free from its connection with Emily's body as the intensity rises in her voice, speeding over the moorland in wide shots that render it 
sublime, the words and views entwining. The sequence culminates in a cut from Charlotte to Emily standing on a rocky outcrop at the edge of a spectacular valley landscape in prospect view. The camera swirls out and over the ravine, aligned with the dynamic, passionate emotion of her words and delivery. It then circles Emily in a sweeping aerial shot that privileges her figure - positioned as an extension of the ancient crag of stone she stands upon - rather than the sublime view. This shot centres her experience with this landscape and her authorship of these words that Charlotte claims as extraordinary. As much as this moment glories in the transcendental majesty of the view, it also glories in Emily's creative labour, using landscape and camerawork to embody the affective experience her poetry creates in both Charlotte and the viewer. The sequence closes with a crossfade, the long shot focused on Emily as she stares out across the valley is replaced with Charlotte in medium close-up, the crossfade immersing Emily's figure into Charlotte's face as the poem ends. The landscapes and emotions her sister's work have catalysed are enclosed back into Charlotte's mind as her body heaves with emotion.

This sequence offers a modification of conventional readings of the sublime as 'driven by Romantic imperatives - the spiritual interplay between the human figure and the engulfing landscapes' (Monk 2011: 45). The sequence ends by centralising Emily within the landscape, rather than framed behind her looking out in prospect view, thus giving her the spiritual power evoked by the landscape and her verse in voiceover. The sequence draws out the affective impact of Emily's poetry by interweaving Charlotte's domestic, stationary encounter with her sister's notebook with dynamic camerawork that evokes Emily's relationship with the landscape, positioning this as inseparable from her art. Here Wainwright builds a highly affective intertwining of female voice, creative labour and West Yorkshire landscapes.

\section{Wainwright's West Yorkshire Women}

To Walk Invisible departs from this special issue's focus on RED Production, but it is valuable to this article's articulation of Wainwright's investment in the emotional dynamics of her protagonists and the West Yorkshire landscape's blend of the everyday and the sublime. The programmes discussed here all feature practical and blunt women who struggle with complex emotional lives both mirror and are rooted in this earthy, brutal yet majestic space, and each weaves different emotions onto these West Yorkshire 
landscapes. In Last Tango in Halifax this is both a practical, labouring landscape linked to Gillian and her farm, and a history-laden leisure-space that offers moments of sublime romanticism through which Alan and Celia's romance is read. Happy Valley's compositional choices layer Catherine's emotional turmoil and repercussions of Tommy's violence onto the town and surrounding valley, building an oppressive affect that sets the valley as the bounded space of melodrama. To Walk Invisible interweaves the Brontë sisters' familial pain, their creative labour and their gothic imagination with their connection to the region's moorland. This interpretation of the sisters' lives positions them as the root of the paired sense and sensibility I find in repeated returns to women's lives in this triangle of West Yorkshire.

Closing with this analysis of an intensely affective moment linked to female voice and sublime landscapes allows me to loop the discussion of Wainwright back to the West Yorkshire place-image I set out at the beginning of this article. These programmes are the latest layer of female voices and images that render the place-image as one of brutal beauty, wrought through melodrama and the gothic. This reads the region through a frame of female melodrama and affective landscape rather than the malefocused social realism that it has typically been connected with. In this way we can view Wainwright's work as a continuation of RED Production's investment in regional writers and articulations of Northern lives that rework traditions of social realism through dynamic, stylised aesthetics (Cooke, 2005:198-190). I have offered here a gendered reading of television's recent 'spatial shift', positioning West Yorkshire as indelible part of Sally Wainwright's storytelling. Her voice draws from and contributes to a placeimage woven from a tapestry of female voices and views, which shape an affective encounter with this land.

Atkins, W.(2015), The Moor: A Journey into the English Wilderness,. London: Faber \& Faber.

Cooke, L. (2005), 'The new social realism of Clocking Off', in J. Bignell \& St. Lacey (eds) Popular Television Drama: Critical Perspectives. Manchester: Manchester University Press, pp. 183-197.

Donaldson, L.F. (2016), 'Series spaces: Revisiting and re-evaluating Inspector Morse.' The Journal of Popular Television, 4: 1, pp. 3-28.

Drabble, M. (2011), 'Fay Godwin at the National Media Museum.' Guardian, January 8, 2011. https://www.theguardian.com/artanddesign/2011/jan/08/margaretdrabble-fay-godwin. 
Gorton, K. (2016), 'Feeling northern: 'Heroic women' in Sally Wainwright's Happy Valley (BBC One, 2014-).' Journal for Cultural Research, 20:1, pp. 73-85.

Helsinger, E. K. (2014), Rural scenes and national representation: Britain, 18151850,Princeton, NJ.: Princeton University Press.

Higson, A. (1984), 'Space, place, spectacle', Screen, 25:4-5, pp. 2-21.

_-_ (2010), Film England: Culturally English filmmaking since the 1990s, London : I.B.Tauris.

Hockenhull, S. (2016), 'Picturesque, pastoral and dirty: Uncivilised topographies in Jane Eyre and Wuthering Heights', in P. Newland (ed.) British rural landscapes on film, Manchester: Manchester University Press, pp. 148-61.

Hughes, T. and F. Godwin (1979), Remains of Elmet, 1st edition, London: Faber and Faber.

Jacobus, M. (1981), 'Book Review: The madwoman in the attic: The woman writer and the nineteenth-century imagination. Sandra M. Gilbert, Susan Gubar. Shakespeare's sisters: Feminist essays on women poets. Sandra M. Gilbert, Susan Gubar', Signs: Journal of Women in Culture and Society, 6:3, pp. 517-23.

Lawrence, M. (2016), 'Nature and the non-human in Andrea Arnold's Wuthering Heights', Journal of British Cinema and Television, 13:1, pp. 177-94.

Maier, S. (2016), 'Biographical myths and legends of the Brontës', in D. Long Hoeveler and D. Denenholz Morse (eds), A Companion to the Brontes, Hoboken: WileyBlackwell, 579-92.

McElroy, R. (2017), 'The feminisation of contemporary British television drama: Sally Wainwright and Red Production', in R. Moseley, H. Wheatley, and H. Wood (eds) Television for women: New directions, Abingdon: Routledge, pp. 34-53.

Monk, C. (2011), 'Eyre conditioning', Sight \& Sound, 21:10, pp. 44-45.

Moseley, R. (2013), 'Women at the edge: Encounters with the Cornish coast in British film and television. Continuum, 27:5, pp. 644-62.

Nowell-Smith, G. (1977), 'Dossier on melodrama: Minnelli and melodrama', Screen, 18:2, pp. 113-18.

Peterson, J. (2010), 'The front lawn of heaven: Landscape in Hollywood melodrama circa 1945', Camera Obscura: Feminism, Culture, and Media Studies, 25:2, pp. 11959.

Phillips, H. (2017). "A woman like that is not a woman, quite. I have been her kind": Maxine Peake and the gothic excess of Northern femininity', in B. Johnson and D. Forrest (eds) Social Class and Television Drama in Contemporary Britain, London: Palgrave Macmillan, pp. 149-64.

Piper, H. (2016), 'Broadcast drama and the problem of television aesthetics: Home, nation, universe', Screen, 57:1, pp. 163-83.

_-_- (2017), 'Happy Valley: Compassion, evil and exploitation in an ordinary "Trouble Town'"', in in B. Johnson and D. Forrest (eds) Social Class and Television Drama in Contemporary Britain, London: Palgrave Macmillan, pp. 181-97.

Plath, S. (2002), Collected Poems. T. Hughes (ed.), London: Faber \& Faber.

Roberts, L. (2016), 'Landscapes in the frame: Exploring the hinterlands of the British procedural drama', New Review of Film and Television Studies, 14: 3, pp. 364-85.

Shields, R. (1992), Places on the margin: Alternative geographies of modernity, London: Routledge.

Thornham, S. (2016). '"Not a country at all": Landscape and Wuthering Heights', Journal of British Cinema and Television, 13:1, pp. 214-31.

Waade, A. M. (2017) 'Melancholy in Nordic Noir: Characters, landscapes, light and 
music,' Critical Studies in Television, 12:4, pp. 380-94.

Wainwright, S. (2016), 'Sally Wainwright: "I didn't want To Walk Invisible to be just another period drama"', Radio Times, 29 December,

http://www.radiotimes.com/news/2016-12-29/sally-wainwright-i-didnt-wantto-walk-invisible-to-be-just-another-period-drama/.

Wheatley, H. (2011). 'Beautiful images in spectacular clarity: Spectacular television, landscape programming and the question of (tele)visual pleasure', Screen 52:2, pp. 233-48.

. (2016), Spectacular television : Exploring televisual pleasure. London: I.B. Tauris. 